\title{
Intensive Care Unit Acquired Hypernatremia after Major Surgery is Associated with Urine Concentrating Defect: An Observational Study
}

Philipp Deetjen ( $\nabla$ philipp.deetjen@uk-augsburg.de)

Universitat Augsburg Medizinische Fakultat https://orcid.org/0000-0003-4488-4701

Ulrich Jaschinski

Universitatsklinikum Augsburg

Axel Heller

Universitatsklinikum Augsburg

Research article

Keywords: hypernatremia, major surgery, sodium, renal concentration, urea

Posted Date: July 16th, 2020

DOI: https://doi.org/10.21203/rs.3.rs-41777/v1

License: (c) (i) This work is licensed under a Creative Commons Attribution 4.0 International License.

Read Full License 


\section{Abstract}

Background: Although intensive care acquired hypernatremia is a common event, limited knowledge exists about the pathogenesis of this disorder. The present study attempts to show that patients undergoing major surgery develop hypernatremia in the presence of both high salt and volume load and concentration disorder of the kidney with insufficient sodium excretion.

Methods: In a retrospective study, all patients who were admitted to a 40-bed tertiary surgical intensive care unit of a university hospital from July 2019 to December 2019 with major surgery were examined. Hypernatremia was defined as a sodium value exceeding $145 \mathrm{mmol} / \mathrm{l}$. In addition to the analysis of all patients, complete water and salt balances were performed in a smaller subgroup with 142 patients.

Results: $23.9 \%$ of patients undergoing major surgery developed hypernatremia, whereby hypernatremia was associated with increased mortality. Patients with hypernatremia showed a renal concentration defect with decreased urine sodium concentration (65 (IQR: 44.8-90) mmol// vs 78 (IQR: 46-107) mmol/l, $\mathrm{p}=0.007$ ) and decreased urine osmolality (514 (IQR: 465-605) mmol/I vs 602 (IQR: 467-740) mmol/l, $\mathrm{p}<$ 0.001). In the subgroup of patients with complete sodium and water balance, a positive salt and water balance was observed. After propensity score matching, we found a significantly increased electrolyte free water clearance $(1020 \pm 1740 \mathrm{ml}$ vs $-560 \pm 1620 \mathrm{ml}, \mathrm{p}<0.001)$ in the hypernatremia group, together with an inadequately lower total sodium urine excretion ( $401 \pm 303 \mathrm{mmol}$ vs $593 \pm 400 \mathrm{mmol}, p=0.02)$.

Conclusion: The present study shows that postoperative hypernatremia is associated with an imbalance between perioperative salt and water load and renal sodium and water handling with inadequately low renal sodium excretion and inadequately high renal water excretion. The underlying renal concentration disorder may be explained by a defect in a natriuretic-ureotelic response a recently described renal ureamediated water conservation mechanism after salt exposure.

\section{Backround:}

Hypernatremia is a frequently encountered phenomenon in intensive care patients and is associated with increased mortality [1-4]. In a large point prevalence study, hypernatremia occurred in $15.8 \%$ and was identified as an independent predictor of increased mortality [5]. However, mechanisms leading to ICU acquired hypernatremia are not clearly defined. Different reasons are proposed ranging from osmotic diuresis, volume therapy, use of diuretics, renal dysfunction or non-renal water loss [6].

A recently published study introduces a new concept of how the organism responds to an increased salt exposure. The authors describe this as a natriuretic-ureotelic regulation [7]. Contrary to conventional belief, the kidneys are able to excrete salt without losing additional osmotic driven water. A renal ureamediated water conservation mechanism is assumed to play a crucial role here. In response to salt exposure, urea transporters are increasingly expressed in the kidney, mainly in the distal collecting tube, leading to elevated renal medullary urea content. This increased urea content acts as an osmotic force for reabsorption of water in the collecting tube. 
This regulatory response to increased dietary salt consumption can possibly be transferred to a scenario in which salt exposure is caused by the administration of saline solutions. Perhaps similar mechanisms are triggered here to ensure that salt and water are excreted in an appropriate ratio. And probably ICU acquired hypernatremia could be explained by a combination of salt exposure during volume loading and impaired renal urine-concentrating ability due to missing natriuretic-ureotelic response.

Perioperatively during major surgery, patients are exposed to high salt loads within a short time, making this period suitable for studying the renal response. The present retrospective study aims to characterize the development of hypernatremia in postoperative patients. The main objective is to find evidence for a disturbed urine concentration in the sense of an impaired natriuretic-ureotelic response in this group of patients. To the authors' knowledge, it is the first time that this new concept is applied to perioperative patients under volume and salt load.

\section{Methods:}

This is a retrospective study that we conducted in a 40-bed tertiary surgical intensive care unit of the University Medical Center Augsburg. We screened a database of all patients (1375) admitted between July 2019 and December 2019. Data was extracted from the patient data management system (Orbis Agfa, Bonn Germany). The following patient characteristics were used: age, gender, Simplified Acute Physiology Score (SAPS) II, type of surgery, in-hospital mortality, and if available routine daily measurements of serum and urine electrolytes, urea, osmolality and creatinine. Due to our patient database management system water balances as well as sodium and potassium content of all supplied substances are automatically recorded in our electronic chart. It is part of our daily routine that $24 \mathrm{~h}$ urine analyses are regularly performed.

We defined hypernatremia as a serum sodium value exceeding $145 \mathrm{mmol} / \mathrm{l}$. In the analysis of all patients, we examined in the group with normonatremic patients the values available within the first four days after surgery as long as the patients were still in the intensive care unit. The hypernatremia group comprised all patients who developed hypernatremia during their intensive care stay. The patients were only included, if the onset of hypernatremia occurred less than four days after surgery. The next four days were examined from that point on. We always used the first serum values of the day.

From the existing values of the four days for serum sodium, urine sodium and urine osmolality we calculated average values. The maximum values and the duration of hypernatremia refer to the entire intensive care unit stay.

For the SAPS II values, we recorded the highest value that occurred within the first 96 hours examined. In order to record a SAPS II score independently from hypernatremia, which is included in the score, one point was subtracted from the score on days the patients developed hypernatremia, as already described elsewhere [8]. 
Since we only wanted to select and examine patients who developed hypernatremia in the intensive care unit after major surgery, we excluded all patients without surgery, neurosurgical patients, patients with hyponatremia ( $<135 \mathrm{mmol} / \mathrm{l})$ or hypernatremia already present at admission and patients under the age of 18. Beyond that, we only included patients with major surgery (Fig. 1).

Of the 168 patients with hypernatremia, 71 patients had enough urine values, which enabled a complete balancing over the first three or four postoperative days. These 71 hypernatremic patients could be compared with 71 normonatremic patients who did not differ significantly regarding water and sodium intake perioperatively on day one and water intake over the entire three or four days. For further analysis, two subgroups were formed within the normonatremic patients. These subgroups were divided into patients $(n=29)$ who had no urine sodium values above $100 \mathrm{mmol} / \mathrm{l}$ and patients $(n=42)$ who reached values above $100 \mathrm{mmol} / \mathrm{l}$ (Fig. 1).

We calculated an electrolyte free water balance (EFWC) using the following formula [6]:

EFWC $=$ Urine Volume $x\left(1-\left(\left[\mathrm{Na}^{+}\right]_{\text {Urine }}+\left[\mathrm{K}^{+}\right]_{\text {Urine }} /\left[\mathrm{Na}^{+}\right]_{\text {Serum }}\right)\right)$

Additionally, to show the difference between the sodium concentration of the input side and the urine sodium concentration, we calculated a non-isotonic sodium balance determining the sodium load which is not isotonic:

Non-isotonic Sodium Balance $=$ Sodium Intake $-\left[\mathrm{Na}^{+}\right]$Urine $x$ Urine Volume

$-\left[\mathrm{Na}^{+}\right]_{\text {serum, day before }} \mathrm{X}$ Isotonic Loss

- $\left[\mathrm{Na}^{+}\right]_{\text {serum, day before }}$ (Water Intake - Urine Volume - Isotonic Loss)

In the non-isotonic sodium balance as well as in the sodium and potassium balance, we did not include any not clearly determinable quantities like perspiratio, or other body fluids like stool or reflux, because either volume or sodium content could only be estimated. Nethertheless, these fluid losses were included in the water balance.

For calculating the tonicity of the added solutions, we used only the sodium concentration with the following formula:

Tonicity of Total Intake = Total Sodium Intake / Total Water Intake

For comparing the drugs applied, we used the maximum dose per day of loop diuretics, hydrocortisone, argipressin and norepinephrine within the 4 days studied.

\section{Statistical analysis}

Data were analysed using $\mathrm{R}$ version 4.0.0 with the following external packages: Table1, sjPlot, sjmisc, rms, Matchlt, coin [9]. Means were reported with standard deviations and medians with their interquartile 
ranges. The nonparametric Fisher's Exact Test was used with categorical data and the nonparametric Mann-Whitney $\mathrm{U}$ test with numerical data because data was not normally distributed. Statistical significance was set at a $\mathrm{p}$ value of less than 0.05 for all tests. Multivariable logistic regression analysis was used to explore the association between sodium as exposure and hospital mortality as outcome. Logistic regression models were also used to study the association of urine sodium concentration, nonisotonic sodium balance and various factors such as diuretic use, hydrocortisone and catecholamines with the development of hypernatremia. We checked for non-linear relationships between continuous covariates and the log-odds using restricted cubic splines. Hypernatremia was used as the dependent variable. We applied propensity score matching in the fully balanced hypernatremic and normonatremic patients by using as matching variable total water intake, total sodium intake, cumulative argipressin dose, cumulative loop diuretic dose, cumulative hydrocortisone dose and cumulative norepinephrine dose (Fig. 1). 
Table 1

Characteristics, hospital mortality and sodium values of all patients and patients with major surgery

\section{All \\ Patients \\ Patients with major \\ surgery}

\begin{tabular}{|c|c|c|c|c|}
\hline $\begin{array}{l}\text { Normal } \\
\text { Sodium } \\
(n= \\
1068)\end{array}$ & $\begin{array}{l}\text { Hypernatremia } \\
(\mathrm{n}=307)\end{array}$ & $\begin{array}{l}\mathrm{P} \text { - } \\
\text { value }\end{array}$ & $\begin{array}{l}\text { Normal } \\
\text { Sodium } \\
(n= \\
535)\end{array}$ & $\begin{array}{l}\text { Hypernatremia } \\
(\mathrm{n}=168)\end{array}$ \\
\hline
\end{tabular}

Department, number

$(\%)$

\begin{tabular}{|c|c|c|c|c|c|c|}
\hline Abdominal Surgery & $\begin{array}{l}170 \\
(15.9 \%)\end{array}$ & $46(15.0 \%)$ & & $\begin{array}{l}122 \\
(22.8 \%)\end{array}$ & $41(24.4 \%)$ & \\
\hline $\begin{array}{l}\text { Gynaecological } \\
\text { Surgery }\end{array}$ & $40(3.7 \%)$ & $4(1.3 \%)$ & & $\begin{array}{l}26 \\
(4.9 \%)\end{array}$ & $4(2.4 \%)$ & \\
\hline $\begin{array}{l}\text { Head and Neck } \\
\text { Surgery }\end{array}$ & 7 (0.7\%) & $7(2.3 \%)$ & & $5(0.9 \%)$ & $3(1.8 \%)$ & \\
\hline Cardiac Surgery & $\begin{array}{l}306 \\
(28.7 \%)\end{array}$ & $88(28.7 \%)$ & & $\begin{array}{l}245 \\
(45.8 \%)\end{array}$ & $74(44.0 \%)$ & \\
\hline Neurosurgery & $\begin{array}{l}152 \\
(14.2 \%)\end{array}$ & $54(17.6 \%)$ & & - & - & \\
\hline Trauma Surgery & $\begin{array}{l}137 \\
(12.8 \%)\end{array}$ & $35(11.4 \%)$ & & $\begin{array}{l}85 \\
(15.9 \%)\end{array}$ & $25(14.9 \%)$ & \\
\hline Urological Surgery & 37 (3.5\%) & $6(2.0 \%)$ & & $\begin{array}{l}24 \\
(4.5 \%)\end{array}$ & $5(3.0 \%)$ & \\
\hline Miscellaneous & $\begin{array}{l}175 \\
(16.4 \%)\end{array}$ & $43(14.0 \%)$ & & - & - & \\
\hline Male, number (\%) & $\begin{array}{l}628 \\
(58.8 \%)\end{array}$ & $180(58.6 \%)$ & ns & $\begin{array}{l}340 \\
(63.6 \%)\end{array}$ & $103(61.3 \%)$ & ns \\
\hline Age, years & $\begin{array}{l}64.9 \pm \\
16.2\end{array}$ & $67.4 \pm 15.8$ & 0.011 & $\begin{array}{l}65.9 \pm \\
15.1\end{array}$ & $68.6 \pm 14.3$ & 0.02 \\
\hline SAPS II score & $\begin{array}{l}33[25- \\
41.5]\end{array}$ & $41[33.3-48.8]$ & $\begin{array}{l}< \\
0.001\end{array}$ & $\begin{array}{l}33[26- \\
41]\end{array}$ & $42[36-51]$ & $\begin{array}{l}<.001 \\
0.00\end{array}$ \\
\hline $\begin{array}{l}\text { SAPS II corrected } \\
\text { score }\end{array}$ & $\begin{array}{l}33[25- \\
41.5]\end{array}$ & $40[33-48]$ & $<.001$ & $\begin{array}{l}33[26- \\
41]\end{array}$ & $41[36-51]$ & ¿. 001 \\
\hline
\end{tabular}

Results are presented as median [interquartile range], as means \pm standard deviations or as absolute number (\%). In the group with major surgery patients, all patients were excluded without major surgery, neurosurgical patients, patients with hyponatremia $(<135 \mathrm{mmol} / \mathrm{l})$ or hypernatremia already at admission. In case of non-significance, the results are presented as "ns". Abbreviations: SAPS II, Simplified Acute Physiology Score 


\begin{tabular}{|c|c|c|c|c|c|c|}
\hline \multirow[b]{2}{*}{$\begin{array}{l}\text { Serum creatinine } \\
(\mathrm{mg} / \mathrm{dl})\end{array}$} & \multicolumn{3}{|c|}{$\begin{array}{l}\text { All } \\
\text { Patients }\end{array}$} & \multicolumn{3}{|c|}{$\begin{array}{l}\text { Patients with major } \\
\text { surgery }\end{array}$} \\
\hline & $\begin{array}{l}0.84 \\
{[0.69-} \\
1.13]\end{array}$ & $\begin{array}{l}0.98[0.7- \\
1.56]\end{array}$ & $<.001$ & $\begin{array}{l}0.87 \\
{[0.72-} \\
1.15]\end{array}$ & $\begin{array}{l}1.11[0.75- \\
1.76]\end{array}$ & $\dot{0} 001$ \\
\hline $\begin{array}{l}\text { Hospital mortality, } \\
\text { number }(\%)\end{array}$ & $\begin{array}{l}104 \\
(9.7 \%)\end{array}$ & 79 (25.7\%) & $<.001$ & $\begin{array}{l}32 \\
(6.0 \%)\end{array}$ & 41 (24.4\%) & $<.001$ \\
\hline $\begin{array}{l}\text { Maximum serum } \\
\text { sodium }(\mathrm{mmol} / \mathrm{l})\end{array}$ & & \multicolumn{2}{|l|}{149 [147-153] } & \multicolumn{3}{|c|}{149 [147-153] } \\
\hline $\begin{array}{l}\text { Number of days } \\
\text { Hypernatremia (days) }\end{array}$ & & \multicolumn{2}{|l|}{$3[1-6]$} & \multicolumn{3}{|c|}{$3[1-6]$} \\
\hline $\begin{array}{l}\text { Onset Hypernatremia } \\
\text { after Surgery (days) }\end{array}$ & & \multicolumn{2}{|l|}{$1[0-3]$} & \multicolumn{3}{|c|}{$1[0-2]$} \\
\hline \multicolumn{7}{|c|}{$\begin{array}{l}\text { Results are presented as median [interquartile range], as means } \pm \text { standard deviations or as absolute } \\
\text { number (\%). In the group with major surgery patients, all patients were excluded without major } \\
\text { surgery, neurosurgical patients, patients with hyponatremia }(<135 \mathrm{mmol} / \mathrm{I}) \text { or hypernatremia already } \\
\text { at admission. In case of non-significance, the results are presented as "ns". Abbreviations: SAPS II, } \\
\text { Simplified Acute Physiology Score }\end{array}$} \\
\hline
\end{tabular}

\section{Results:}

Patient characteristics are shown in Table 1 . The incidence of hypernatremia was $22.3 \%$ in all patients. In the cohort of selected major surgery patients, the incidence was $23.9 \%$. SAPS II values within the examined four days showed a median of 42 (IQR: 36-51) in the hypernatremia group and 33 (IQR: 26$41)$ in the group with normal sodium values. The maximum sodium value developed by patients with hypernatremia was 149 (IQR: 147-153) mmol/l, hypernatremia persisted for a median of 3 (IQR: 1-6) days. The interval from surgery to the first hypernatremic values measured a median of 1 (IQR: 0-2) days.

The hospital mortality rate in the hypernatremia group was $24.4 \%$ and in the group with normal sodium values $6 \%$. A logistic regression model adjusted for creatinine, age and gender revealed a significant association of increased hospital mortality with SAPS II values (OR 1.07 (95\% Cl 1.04-1.1), p < 0.001) and development of hypernatremia (OR 2.6 (95\% Cl 1.42-4.79), $p=0.002)$ (Additional file, Table S1).

Table 2 shows the average values obtained in the first four days after surgery in the group with normal sodium values, if available, and the average values obtained in the first four days of the hypernatremia group after development of hypernatremic values. In the hypernatremia group, the median urine sodium values (65 (IQR: $44.8-90) \mathrm{mmol} / \mathrm{I}$ versus 78 (IQR: 46-107) $\mathrm{mmol} / \mathrm{l}, \mathrm{p}=0.007$ ) and the urine osmolality values (514 (IQR: 465-605) mmol/I versus 602 (IQR: 467-740) mmol/l, $\mathrm{p}<0.001$ ) were lower. 
Table 2

Serum and urine mean values collected within four postoperative days after major surgery.

\begin{tabular}{|llll|}
\hline & $\begin{array}{l}\text { Normal Sodium } \\
(\mathbf{n = 5 3 5 )}\end{array}$ & $\begin{array}{l}\text { Hypernatremia } \\
(\mathbf{n = 1 6 8 )}\end{array}$ & P-value \\
\hline Serum Sodium $(\mathrm{mmol} / \mathrm{l})$ & $139[138-141]$ & $146[144-148]$ & $<0.001$ \\
\hline Urine Sodium $(\mathrm{mmol} / \mathrm{l})$ & $78[46-107]$ & $65[44.8-90]$ & 0.007 \\
\hline Urine Osmolality $(\mathrm{mmol} / \mathrm{l})$ & $602[467-740]$ & $514[465-605]$ & $<0.001$ \\
\hline Urine Urea (mmol/l) & $209[138-282]$ & $198[150-254]$ & $\mathrm{ns}$ \\
\hline $\begin{array}{l}\text { Results are presented as median [interquartile range]. In case of non-significance, the results are } \\
\text { presented as "ns". }\end{array}$ & & & \\
\hline
\end{tabular}

A similar pattern was seen in the group of 142 patients with complete water and sodium balance (Table 3). Sodium and water intake on day of surgery and total water intake over the first four postoperative days did not differ significantly between patients with hypernatremia and patients with normal sodium values. As with the entire cohort, patients with hypernatremia had lower values of urine sodium (52.8 (IQR: $37-70.7) \mathrm{mmol} / \mathrm{l}$ versus 83.5 (IQR: $47.5-110) \mathrm{mmol} / \mathrm{l}, \mathrm{p}<0.001)$, urine osmolality (515 (IQR: $480-614) \mathrm{mmol} / \mathrm{I}$ versus 648 (IQR: $553-733) \mathrm{mmol} / \mathrm{l}, \mathrm{p}<0.001)$ and urine urea (204 (IQR: 153253) $\mathrm{mmol} / \mathrm{l}$ versus 250 (IQR: 183-313), $\mathrm{p}=0.01$ ) than patients with normonatremia (Table 3 and Fig. 2). 
Table 3

Balances and serum and urine values of patients with complete data after major surgery

\begin{tabular}{|c|c|c|c|}
\hline & $\begin{array}{l}\text { Normal } \\
\text { Sodium } \\
(n=71)\end{array}$ & $\begin{array}{l}\text { Hypernatremia } \\
(n=71)\end{array}$ & $\begin{array}{l}\mathrm{P} \text { - } \\
\text { value }\end{array}$ \\
\hline Sodium intake day of surgery (mmol) & $862 \pm 382$ & $917 \pm 477$ & ns \\
\hline Water intake day of surgery (I) & $6280 \pm 2640$ & $6600 \pm 3270$ & ns \\
\hline Total water intake $(\mathrm{I})$ & $13500 \pm 3640$ & $14200 \pm 4740$ & ns \\
\hline Total sodium intake (mmol) & $1570 \pm 562$ & $1870 \pm 690$ & 0.002 \\
\hline $\begin{array}{l}\text { Tonicity of total intake as sodium concentration } \\
(\mathrm{mmol} / \mathrm{l})\end{array}$ & $115 \pm 19.1$ & $131 \pm 15.9$ & $<.001$ \\
\hline Total urine sodium excretion (mmol) & $547 \pm 364$ & $381 \pm 270$ & 0.005 \\
\hline Total sodium balance (mmol) & $547 \pm 462$ & $938 \pm 522$ & $\begin{array}{l}<.001 \\
0.001\end{array}$ \\
\hline Total water balance $(\mathrm{I})$ & $1760 \pm 2580$ & $2260 \pm 3990$ & ns \\
\hline Total potassium balance (mmol) & $-193 \pm 104$ & $-196 \pm 110$ & ns \\
\hline Total urea balance $(\mathrm{mmol})$ & $-974 \pm 588$ & $-1040 \pm 685$ & ns \\
\hline EFWC (ml) & $-373 \pm 1610$ & $1070 \pm 1560$ & $\begin{array}{l}<.001 \\
0.01\end{array}$ \\
\hline Non-isotonic sodium balance (mmol) & $-19.3 \pm 247$ & $363 \pm 317$ & $\begin{array}{l}<.001 \\
0.001\end{array}$ \\
\hline Maximum loop diuretic dose per day (mg) & $11.8 \pm 18.6$ & $15.1 \pm 20$ & ns \\
\hline Maximum argipressin dose per day (IE) & $3.39 \pm 8.85$ & $9.28 \pm 13.7$ & 0.001 \\
\hline Maximum hydrocortisone dose per day (mg) & $37.2 \pm 69.7$ & $104 \pm 102$ & $\begin{array}{l}<.001 \\
0.001\end{array}$ \\
\hline Maximum norepinephrine dose per day (mg) & $12.4 \pm 12.7$ & $22.6 \pm 18.3$ & $\begin{array}{l}<.001 \\
0.001\end{array}$ \\
\hline SAPS II corrected & $36[31.3-43]$ & $46[36-53]$ & $<.001$ \\
\hline
\end{tabular}

Serum sodium, urine sodium, urine osmolality and urine urea are mean values collected within four postoperative days. For patients with propensity score matching, the following matching variables were applied: total water intake, total sodium intake, maximum argipressin dose per day, maximum loop diuretic dose per day, maximum hydrocortisone dose per day, maximum norepinephrine dose per day. Results are presented as median [interquartile range] or as means \pm standard deviations. In case of non-significance, the results are presented as "ns". Abbreviations: SAPS II, Simplified Acute Physiology Score; EFWC, electrolyte free water clearance 


\begin{tabular}{|c|c|c|c|}
\hline & $\begin{array}{l}\text { Normal } \\
\text { Sodium } \\
(n=71)\end{array}$ & $\begin{array}{l}\text { Hypernatremia } \\
(n=71)\end{array}$ & $\begin{array}{l}\mathrm{P}- \\
\text { value }\end{array}$ \\
\hline Serum Sodium (mmol/l) & 139 [138-140] & $144[143-145]$ & $<.001$ \\
\hline Urine Sodium (mmol/l) & $\begin{array}{l}83.5[47.5- \\
110]\end{array}$ & $52.8[37-70.7]$ & $\begin{array}{l}< \\
0.001\end{array}$ \\
\hline Urine Osmolality (mmol/l) & $648[553-733]$ & $515[480-614]$ & $\begin{array}{l}< \\
0.001\end{array}$ \\
\hline Urine Urea $(\mathrm{mmol} / \mathrm{l})$ & $250[183-313]$ & $204[153-253]$ & 0.01 \\
\hline After propensity score matching & $(n=47)$ & $(n=47)$ & \\
\hline Serum Sodium (mmol/l) & $140[138-140]$ & $144[143-145]$ & $\begin{array}{l}< \\
0.001\end{array}$ \\
\hline Urine Sodium (mmol/l) & $\begin{array}{l}99.5 \text { [49.3- } \\
118]\end{array}$ & $52.8[37-77.9]$ & $\begin{array}{l}<.001 \\
0.001\end{array}$ \\
\hline Urine Osmolality $(\mathrm{mmol} / \mathrm{l})$ & $648[552-723]$ & $560[477-632]$ & 0.007 \\
\hline EFWC (ml) & $-560 \pm 1620$ & $1020 \pm 1740$ & $\begin{array}{l}< \\
0.001\end{array}$ \\
\hline Non-isotonic sodium balance (mmol) & $51.7 \pm 238$ & $298 \pm 336$ & $\begin{array}{l}<.001 \\
0.001\end{array}$ \\
\hline Total urine sodium excretion (mmol) & $593 \pm 400$ & $401 \pm 303$ & 0.02 \\
\hline SAPS II corrected & $36.5[32-43]$ & 39 [35.5-49.5] & 0.03 \\
\hline \multicolumn{4}{|c|}{$\begin{array}{l}\text { Serum sodium, urine sodium, urine osmolality and urine urea are mean values collected within four } \\
\text { postoperative days. For patients with propensity score matching, the following matching variables } \\
\text { were applied: total water intake, total sodium intake, maximum argipressin dose per day, maximum } \\
\text { loop diuretic dose per day, maximum hydrocortisone dose per day, maximum norepinephrine dose per } \\
\text { day. Results are presented as median [interquartile range] or as means } \pm \text { standard deviations. In case } \\
\text { of non-significance, the results are presented as "ns". Abbreviations: SAPS II, Simplified Acute } \\
\text { Physiology Score; EFWC, electrolyte free water clearance }\end{array}$} \\
\hline
\end{tabular}

The total sodium balance was higher in the hypernatremia group (938 $\pm 522 \mathrm{mmol}$ versus $547 \pm 462$, $\mathrm{p}<$ $0.001)$, as was the non-isotonic sodium balance $(363 \pm 317 \mathrm{mmol}$ versus $-19.3 \pm 247, \mathrm{p}<0.001)$ and the EFWC $(1070 \pm 1560 \mathrm{ml}$ versus $-373 \pm 1610, \mathrm{p}<0.001)$ (Table 3 and Fig. 2$)$. In contrast to the lower total sodium urine excretion ( $381 \pm 270 \mathrm{mmol}$ versus $547 \pm 364 \mathrm{mmol}, p=0.005)$, the average tonicity of volume intake was higher $(131 \pm 15.9 \mathrm{mmol} / \mathrm{l}$ versus $115 \pm 19.1 \mathrm{mmol} / \mathrm{l}, \mathrm{p}<0.001)$. Total water balance, total urea balance did not differ. The water balance was positive, whereas the urea balance was negative. The potassium balance was negative in both cases without significant difference.

In order to verify whether the lower urine sodium concentration and the higher tonicity of the added infusion solutions are indeed significantly associated with the development of hypernatremia, we applied 
a multivariate logistic regression model (Additional file, Table S2). After adjusting for loop diuretics, hydrocortisone, argipressin, norepinephrine, total water intake and corrected SAPS II, logistic regression analysis revealed only a significant association with the average urine sodium concentration (OR 0.98 (95\% Cl 0.96-0.99), $\mathrm{p}=0.001)$ and the tonicity of the added volume (OR 1.05 (95\% Cl 1.02-1.08), $\mathrm{p}<$ 0.001) (Additional file, Table S2A). In an additional model we could confirm a significant association between the non-isotonic sodium balance (OR $1.004(95 \% \mathrm{Cl} 1.002-1.007), \mathrm{p}<0.001)$ and the development of hypernatremia as well (Additional file, Table S2B).

In another approach, we used propensity score matching to create groups of hypernatremic and normonatremic patients with adjusted water and salt intake and drug therapy (Table 3, lower part). Although both groups now received infusions with a comparable tonicity and volume, a significant difference could still be seen for urine sodium (52.8 (IQR: $37-77.9) \mathrm{mmol} / \mathrm{I}$ versus 99.5 (IQR: 49.3-118) $\mathrm{mmol} / \mathrm{l}, \mathrm{p}<0.001$ ), urine osmolality (560 (IQR: 477-632) $\mathrm{mmol} / \mathrm{I}$ versus 648 (IQR: $552-723$ ) $\mathrm{mmol} / \mathrm{l}, \mathrm{p}=$ 0.007), non-isotonic sodium balance $(298 \pm 336 \mathrm{mmol}$ versus $51.7 \pm 238 \mathrm{mmol}, \mathrm{p}<0.001)$, EFWC $(1020 \pm$ $1740 \mathrm{ml}$ versus $-560 \pm 1620 \mathrm{ml}, \mathrm{p}<0.001)$, and total urine sodium excretion ( $401 \pm 303 \mathrm{mmol}$ versus 593 $\pm 400 \mathrm{mmol}, \mathrm{p}=0.02$ ) (Table 3 , lower part). The SAPS II value in the hypernatremia group was lower than before due to selection of patients within the propensity score matching.

A subgroup of the fully balanced patients with normonatremia had no increased urine sodium concentration despite sodium exposure (Table 4). Urine urea and urine osmolality in this group did not differ from the values of other patients with normonatremia. However, the total water balance was more positive $(2610 \pm 2770 \mathrm{ml}$ vs. $1180 \pm 2300 \mathrm{ml}, \mathrm{p}=0.01)$ due to reduced total urine volume $(4870 \pm 1820 \mathrm{ml}$ vs. $7110 \pm 2190 \mathrm{ml}, \mathrm{p}<0.001$ ) (Table 4 and Fig. 3). After propensity score matching (Table 4, lower part) in order to examine patients with comparable sodium and water load and to avoid differences in tonicity, the reduced urine excretion ( $4870 \pm 1820 \mathrm{ml} v \mathrm{~s} .7180 \pm 2240 \mathrm{ml}, \mathrm{p}<0.001)$ and thus the more positive water balance $(2610 \pm 2770 \mathrm{ml}$ vs. $425 \pm 1960 \mathrm{ml}, \mathrm{p}<0.001)$ could be confirmed significant. 
Table 4

Subgroup of patients with normal sodium values despite low urine sodium $(<100 \mathrm{mmol} / \mathrm{l})$

\begin{tabular}{|c|c|c|c|}
\hline & $\begin{array}{l}\text { Normal Sodium without } \\
\text { increased Urine Sodium } \\
(n=29)\end{array}$ & $\begin{array}{l}\text { Normal Sodium with increased } \\
\text { Urine Sodium } \\
(n=42)\end{array}$ & $\begin{array}{l}\mathrm{P}- \\
\text { value }\end{array}$ \\
\hline $\begin{array}{l}\text { Total water intake } \\
\text { (ml) }\end{array}$ & $12700 \pm 3100$ & $14000 \pm 3910$ & ns \\
\hline $\begin{array}{l}\text { Tonicity of total } \\
\text { intake }(\mathrm{mmol} / \mathrm{l})\end{array}$ & $110 \pm 20.5$ & $118 \pm 17.5$ & ns \\
\hline $\begin{array}{l}\text { Total urine volume } \\
(\mathrm{ml})\end{array}$ & $4870 \pm 1820$ & $7110 \pm 2190$ & $\begin{array}{l}< \\
0.001\end{array}$ \\
\hline $\begin{array}{l}\text { Total sodium balance } \\
(\mathrm{mmol})\end{array}$ & $743 \pm 410$ & $412 \pm 451$ & 0.005 \\
\hline $\begin{array}{l}\text { Total water balance } \\
(\mathrm{ml})\end{array}$ & $2610 \pm 2770$ & $1180 \pm 2300$ & 0.01 \\
\hline $\begin{array}{l}\text { Serum Sodium } \\
(\mathrm{mmol} / \mathrm{l})\end{array}$ & 139 [138-140] & 139 [138-140] & ns \\
\hline $\begin{array}{l}\text { Urine Sodium } \\
(\mathrm{mmol} / \mathrm{l})\end{array}$ & 39.8 [35-57.2] & 109 [92.8-123] & $\begin{array}{l}< \\
0.001\end{array}$ \\
\hline $\begin{array}{l}\text { Urine Osmolality } \\
(\mathrm{mmol} / \mathrm{l})\end{array}$ & $625[540-721]$ & 667 [569-754] & ns \\
\hline Urine Urea $(\mathrm{mmol} / \mathrm{l})$ & 271 [219-322] & 233 [167-297] & ns \\
\hline $\begin{array}{l}\text { After Propensity } \\
\text { score matching }\end{array}$ & $(n=29)$ & $(n=29)$ & \\
\hline $\begin{array}{l}\text { Total urine volume } \\
(\mathrm{ml})\end{array}$ & $4870 \pm 1820$ & $7180 \pm 2170$ & $\begin{array}{l}< \\
0.001\end{array}$ \\
\hline $\begin{array}{l}\text { Total sodium balance } \\
(\mathrm{mmol})\end{array}$ & $743 \pm 410$ & $296 \pm 381$ & $\begin{array}{l}< \\
0.001\end{array}$ \\
\hline $\begin{array}{l}\text { Total water balance } \\
(\mathrm{ml})\end{array}$ & $2610 \pm 2770$ & $425 \pm 1960$ & $\begin{array}{l}< \\
0.001\end{array}$ \\
\hline \multicolumn{4}{|c|}{$\begin{array}{l}\text { Serum sodium, urine sodium, urine osmolality and urine urea are mean values collected within four } \\
\text { postoperative days. For patients with propensity score matching, the following matching variables } \\
\text { were applied: total water intake, total sodium intake, maximum argipressin dose per day, maximum } \\
\text { loop diuretic dose per day, maximum hydrocortisone dose per day, maximum norepinephrine dose per } \\
\text { day. Results are presented as median [interquartile range] or as means } \pm \text { standard deviations. In case } \\
\text { of non-significance, the results are presented as "ns". }\end{array}$} \\
\hline
\end{tabular}

A gradual increase in natriuresis was observed in some normonatriemic patients. The course of this pattern of renal sodium excretion in some patients $(n=27)$ as opposed to patients developing hypernatremia $(n=58)$ is shown in Fig. 4. 


\section{Discussion:}

The present study shows that in surgical intensive care patients undergoing major surgery hypernatremia was a frequent finding with an incidence of $23.9 \%$. We were able to demonstrate that hypernatremia developed within the first days after surgery and was associated with an increased mortality rate.

In regard to the underlying mechanism of hypernatremia in our study, we see evidence for urine concentration defect with lowered urine sodium values and lowered urine osmolality values in all patients developing hypernatremia after major surgery. In patients with complete salt and water balance, an association between the development of hypernatremia and a combination of sodium load and concomitant renal inability to excrete sodium sufficiently was detected. With logistic regression analysis and propensity score matching, we confirm that this association was significant.

The incidence of ICU-acquired hypernatremia in our study is comparable to other studies conducted in surgical and medical intensive care units $[14,16]$. Compared to two studies with exclusively cardiac surgical patients, the incidence and mortality is higher $[2,4]$, which may be partly explained by the more severe degree of disease in our study reflected in higher SAPS II values [2].

Patients undergoing major surgery are exposed to a considerable salt and volume load within a short period of time. Therefore, perioperative patients are very suitable to study how the body handles salt exposure. In our study, we saw a positive water and salt balance on the day of surgery, which continues until the 4th postoperative day in both hypernatremic and normonatremic patients (Table 3 ).

Normonatremic patients were able to increase their natriuresis as shown by the higher urine sodium levels (Fig. 2 and Table 3). At the same time the urine concentrating capacity was maintained without any additional loss of water reflected by the significantly higher osmolality (Fig. 2 and Table 3). In contrast to this, patients with hypernatremia were not able to increase natriuresis. Simultaneously they lost too much water in relationship to sodium. Hypernatremia developed due to inadequate excretion of free water in relation to the supply of free water. In the balance, this was reflected in a significantly increased amount of non-isotonic sodium in the hypernatremia group and the increased EFWC (Fig. 2 and Table 3). The relevance of the lowered urine sodium concentration and the increased non-isotonic sodium balance was confirmed in the logistic regression analysis (Additional file, S2). The corresponding changes remained significant after propensity score matching (Table 3 ).

In some previous studies, a urine concentration defect in combination with salt exposure already was discussed $[1,6]$. A recently published study proposed a natriuretic-ureotelic adaption in response to salt load introducing a new aspect of renal salt handling [7]. In brief, this model comprises three steps. First, aldosterone must be suppressed to ensure increased salt excretion in the collection tube. Secondly, in order to prevent salt-induced water excretion, the medullary urea concentration is increased via urea transporter, mainly UTA-1, in the distal collecting tube. The increased medullary urea concentration provides the necessary osmotic driving force to avoid inadequate water loss. Thirdly, there is a complex catabolic metabolic conversion with urea production and metabolic water production (Fig. 5). These 
changes, affecting the whole organism besides the kidneys, are described in detail in the abovementioned work on mice that receive salt but do not have sufficient access to water. Evidence for a similar pattern supposed to protect against dehydration can also be found in humans[7].

Certainly, it needs to be discussed to what extent this concept can be applied to the postoperative intensive care situation. In contrast to the probands of the study by Kitada [7], postoperative patients are not only exposed to salt load but also to volume load, which possibly provokes different physiological reactions. Moreover, postoperative patients are exposed to considerable circulatory stress with catecholamine support. Factors such as diuretics and the administration of hydrocortisone may have an additional impact.

Nevertheless, previous studies on volunteers after saline infusions showed how patients were able to excrete sodium and water in adequate ratio [1] with simultaneously suppressed aldosterone [11], consistent with the described concept. Similarly in our study, normonatremic patients reacted with an increase in natriuresis without signs of inadequate water diuresis, despite considerable salt and volume load. Figure 4 shows a subgroup of normonatremic patients with stepwise increase in urine sodium concentration possibly demonstrating the interplay between declining aldosterone and urea driven water conservation mechanism in the collecting duct. Correspondingly in the sodium and water balance, the non-isotonic sodium reaches negative values. In the hypernatremia group, this response does not occur.

Are there other mechanisms explaining the decreased urine sodium concentration and the urine concentrating defect with decreased urine osmolality in patients with hypernatremia? Compared to patients with normal sodium values, hypernatremic patients were sicker supported by the higher corrected and not corrected SAPS II values. They had higher doses of norepinephrine and empressin and received hydrocortisone more frequently (Table 3). However, excessive mineral corticoid stimulation resulting from this seems unlikely to be the only reason, since the inadequate water excretion cannot be explained in this way. Moreover, there was no difference in the potassium balance (Table 3). Supporting this, in logistic regression analysis, no association could be seen between the development of hypernatremia and the administration of loop diuretics, hydrocortisone, noradrenalin or argipressin (Additional file, S2). Interestingly, the potassium balance in both groups was negative as observed in a study with heart surgery patients [12].

In some studies osmotic diuresis is discussed [13]. However, the patients in the present study did not fulfil the criteria of a polyuria with increased urine quantity, did not receive osmotically active substances such as mannitol and did not suffer from excessive blood sugar levels. Criteria for urea-induced osmotic diuresis were also not met [13].

The study by Kita demonstrates how a urea gradient is built up simultaneously to increased natriuresis [7]. The authors can show that UTA-1 urea transporters are increasingly expressed. Conversely, it is known from knockout mice that, in absence of the UTA-1 transporter, a concentration defect occurs, which causes urine to be produced with low osmolality, urea and sodium and inadequate water losses $[14,15]$. 
A pattern with a certain similarity to the patients examined here. Possibly, similar pathophysiological mechanisms are present here in the sense of a defect urea-mediated urine concentration (Fig. 5).

In addition to the renal concentration disorder, other extrarenal factors may be involved causing hypernatremia after surgery. We have to question to what extent balances are at all able to explain changes in sodium concentration [16]. There is evidence that sodium is stored non-osmotically in critically ill patients [17]. Moreover, there are always inaccuracies in the balance due to factors with unknown quantity or unknown sodium concentration like perspiration, gastric juice, stool or internal bleeding. In our study, these factors are not included in the calculation of non-isotonic sodium which does not mean that the non-isotonic sodium is not subject to quantitative error. In terms of quality, however, the difference is very clear and significant, so that the balance of non-isotonic sodium certainly covers the main components contributing to the development of hypernatremia. The significance of the association between hypernatremia and changes in the non-isotonic sodium balance is confirmed by logistic regression analysis (Additional file, S2). Apart from the lack of sodium excretion with simultaneous inadequate water diuresis, it is noticeable that patients with hypernatremia have a higher tonicity of added fluids. However, in both groups the tonicity is below the tonicity of the plasma. The higher tonicity in hypernatremic patients can be explained by the fact that these patients are sicker, receive higher doses of catecholamines and therefore receive isotonic fluids as volume therapy for longer, in contrast to normonatremic patients who get access to free water earlier. With propensity score matching we were able to eliminate the influence of the tonicity of the added volume and reveal that hypernatremic patients have above all a renal urine concentration disturbance (Table 3 ).

In the normonatremic group, there is a subgroup of patients who showed no increase in urine sodium despite similar perioperative volume load (Table 4). This can be explained by the more positive water balance due to lower urine volumes. Apparently this group saves more volume during the examined postoperative 4 days and therefore does not need to increase the sodium concentration in the urine. Hence the renal response to the supply of water and salt is adequate. After propensity score matching, the significantly more positive balance remains in these patients (Table 4, lower part).

A weakness of the present study is its retrospective nature, so a considerable number of patients do not have sufficient data for complete balances, despite our clinical practice of performing regular urine analyses. Indirect evidence for the mechanisms that take place during volume and salt loading can be found with the help of the balances. Whether a natriuretic ureotelic response is indeed the basis of the changes in urine concentrating processes, and whether the development of hypernatremia actually has its origin in a lack of response, can only be shown indirectly on the basis of the described developments.

\section{Conclusion:}

In summary, the study shows that hypernatremia can develop postoperatively after major surgery. We demonstrate that the development of hypernatremia was comprehensible with sodium and water balances. We were able to show for the first time in a larger patient cohort that a defect in urine 
concentration was significantly associated with hypernatremia. We demonstrate that the change in urinary sodium excretion due to a large volume and salt load corresponded to a pattern that could be in line with the natriuretic ureotelic concept and that this response could be impaired in the pathogenesis of hypernatremia. Regarding therapy of hypernatremia, for which hardly any data exists [18], the lower tonicity of the infusion volume seen in our normonatremic patients could be an interesting factor.

\section{List Of Abbreviations}

SAPS II, Simplified Acute Physiology Score II; IQR, interquartile range; OR, odds ratio; $\mathrm{Cl}$, confidence interval;

\section{Declarations}

\section{Ethics approval and consent to participate}

The study protocol was approved by the Institutional Review Board (Beratungskommission für klinische Forschung Universitätklinikum Augsburg, reference number 2019-29). As all data were de-identified, the Institutional Review Board waived the necessity of obtaining informed consent.

\section{Consent for publication}

Not applicable

\section{Availability of data and materials}

The datasets used and analyzed during the current study are available from the corresponding author on reasonable request.

\section{Competing interests}

The authors declare that they have no competing interests.

\section{Funding}

None

\section{Authors' contributions}


PD designed the study, collected the data, performed the statistical analysis and wrote all the draft versions of the manuscript. UJ and $\mathrm{AH}$ supervised and participated in the concept design and study plan. All authors approved the final version of the manuscript.

\section{Acknowledgements}

We would especially like to thank Reinhard Hoffmann and Hans-Georg Ruf for extracting the laboratory data from the laboratory information management system. We are particularly grateful to Dennis Freuer for his support in the statistical analysis.

\section{References}

1. Hoorn EJ, Betjes MGH, Weigel J, Zietse R. Hypernatraemia in critically ill patients: too little water and too much salt. Nephrol Dial Transplant. 2008;23:1562-8.

2. Lindner G, Funk G-C, Lassnigg A, Mouhieddine M, Ahmad S-A, Schwarz C, et al. Intensive careacquired hypernatremia after major cardiothoracic surgery is associated with increased mortality. Intensive Care Med. 2010;36:1718-23.

3. Stelfox HT, Ahmed SB, Khandwala F, Zygun D, Shahpori R, Laupland K. The epidemiology of intensive care unit-acquired hyponatraemia and hypernatraemia in medical-surgical intensive care units. Crit Care. 2008;12:R162.

4. Stelfox HT, Ahmed SB, Zygun D, Khandwala F, Laupland K. Characterization of intensive care unit acquired hyponatremia and hypernatremia following cardiac surgery. Can J Anaesth. 2010;57:6508.

5. Vandergheynst F, Sakr Y, Felleiter P, Hering R, Groeneveld J, Vanhems P, et al. Incidence and prognosis of dysnatraemia in critically ill patients: analysis of a large prevalence study. Eur J Clin Invest. 2013;43:933-48.

6. Lindner G, Funk G-C. Hypernatremia in critically ill patients. J Crit Care. 2013;28:216.e11-20.

7. Kitada K, Daub S, Zhang Y, Klein JD, Nakano D, Pedchenko T, et al. High salt intake reprioritizes osmolyte and energy metabolism for body fluid conservation. J Clin Invest. 2017;127:1944-59.

8. Funk G-C, Lindner G, Druml W, Metnitz B, Schwarz C, Bauer P, et al. Incidence and prognosis of dysnatremias present on ICU admission. Intensive Care Med. 2010;36:304-11.

9. R Core Team. R: A language and environment for statistical computing. R Foundation for Statistical Computing. 2020. URL https://www.R-project.org. Accessed 20 May 2020.

10. Stelfox HT, Ahmed SB, Khandwala F, Zygun D, Shahpori R, Laupland K. The epidemiology of intensive care unit-acquired hyponatraemia and hypernatraemia in medical-surgical intensive care units. Crit Care. 2008;12:R162.

11. Rasmussen MS, Simonsen JA, Sandgaard NCF, Høilund-Carlsen PF, Bie P. Mechanisms of acute natriuresis in normal humans on low sodium diet. J Physiol (Lond). 2003;546:591-603. 
12. Hessels L, Oude Lansink A, Renes MH, van der Horst ICC, Hoekstra M, Touw DJ, et al. Postoperative fluid retention after heart surgery is accompanied by a strongly positive sodium balance and a negative potassium balance. Physiol Rep. 2016;4.

13. Lindner G, Schwarz C, Funk G-C. Osmotic diuresis due to urea as the cause of hypernatraemia in critically ill patients. Nephrol Dial Transplant. 2012;27:962-7.

14. Fenton RA, Chou C-L, Sowersby H, Smith CP, Knepper MA. Gamble's "economy of water" revisited: studies in urea transporter knockout mice. Am J Physiol Renal Physiol. 2006;291:F148-154.

15. Fenton RA, Knepper MA. Urea and renal function in the 21 st century: insights from knockout mice. J Am Soc Nephrol. 2007;18:679-88.

16. van IJzendoorn MCO, Buter H, Kingma WP, Navis GJ, Boerma EC. The Development of Intensive Care Unit Acquired Hypernatremia Is Not Explained by Sodium Overload or Water Deficit: A Retrospective Cohort Study on Water Balance and Sodium Handling. Crit Care Res Pract. 2016;2016:9571583.

17. Hessels L, Oude Lansink-Hartgring A, Zeillemaker-Hoekstra M, Nijsten MW. Estimation of sodium and chloride storage in critically ill patients: a balance study. Ann Intensive Care [Internet]. 2018 [cited 2020 Jun 29];8. Available from: https://www.ncbi.nlm.nih.gov/pmc/articles/PMC6179979/

18. Quinn JW, Sewell K, Simmons DE. Recommendations for active correction of hypernatremia in volume-resuscitated shock or sepsis patients should be taken with a grain of salt: A systematic review. SAGE Open Med. 2018;6:2050312118762043.

\section{Figures}




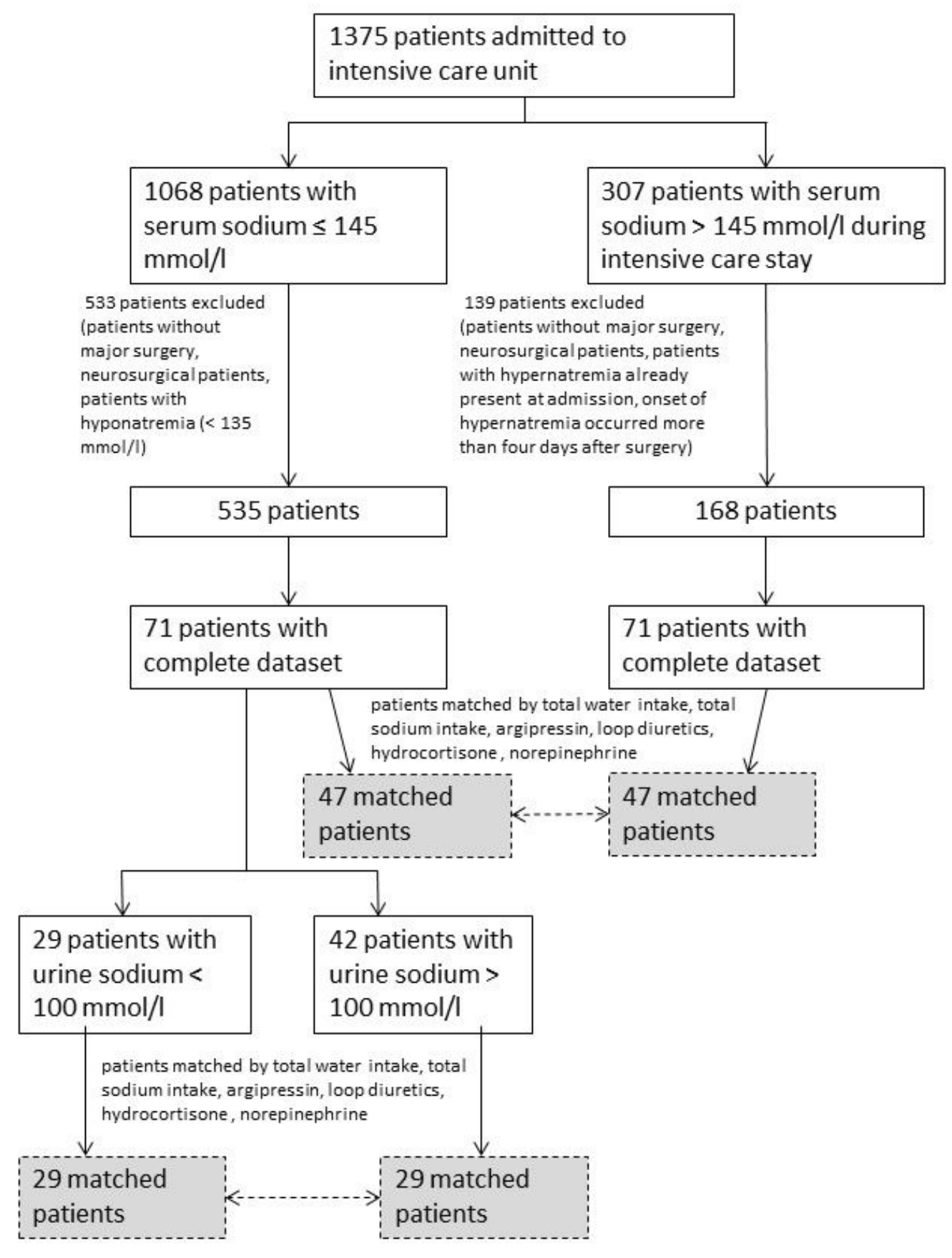

\section{Figure 1}

Flow diagram showing study group selection of patients admitted to a surgical intensive care unit between July 2019 and December 2019. 
A
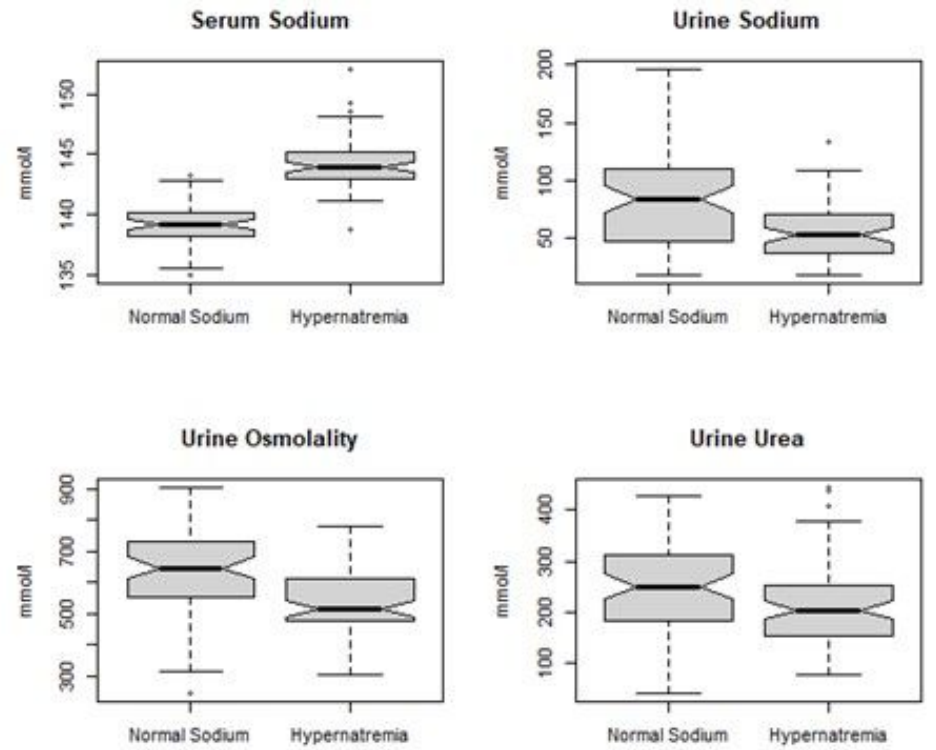

B
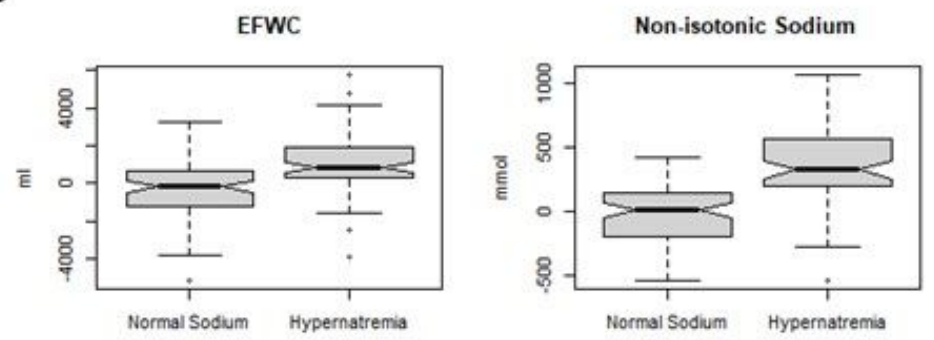

\section{Figure 2}

Serum and urine values of completely balanced patients $(A)$ as well as electrolyte free water clearance (EFWC) and non-isotonic sodium balance (B) with normal sodium $(n=71)$ and hypernatremia $(n=71)$. 

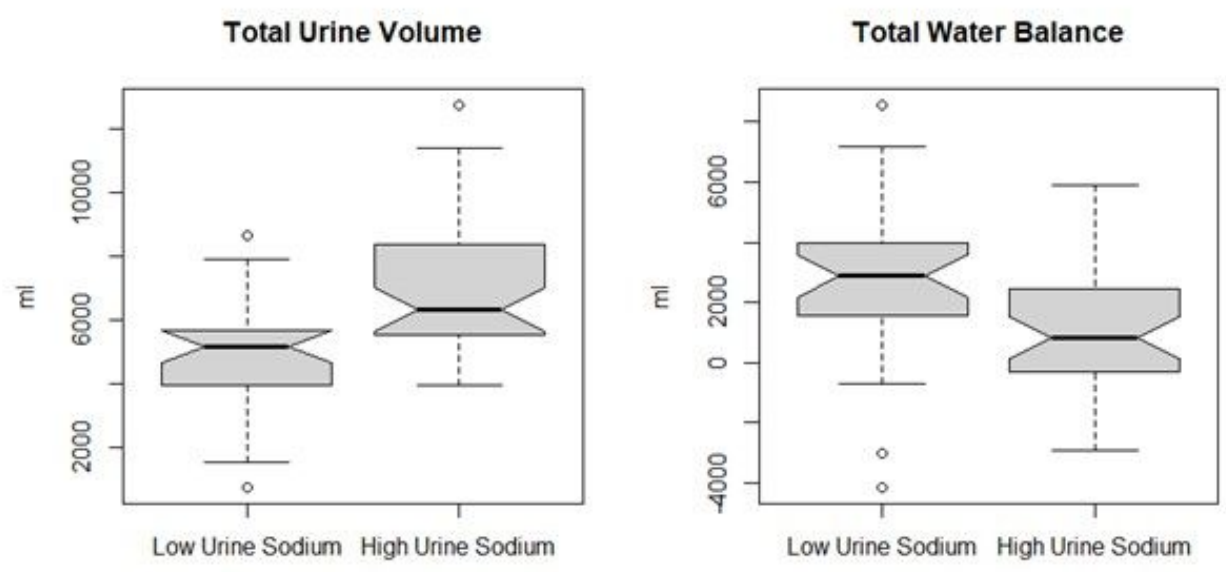

\section{Figure 3}

Subgroup of normonatremic patients divided into patients (low urine sodium, $n=29$ ) who had no urine sodium values above $100 \mathrm{mmol} / \mathrm{I}$ and patients (high urine sodium, $\mathrm{n}=42$ ) who reached values above 100 $\mathrm{mmol} / \mathrm{l}$. The differences in total urine volume and total water balance are shown. 

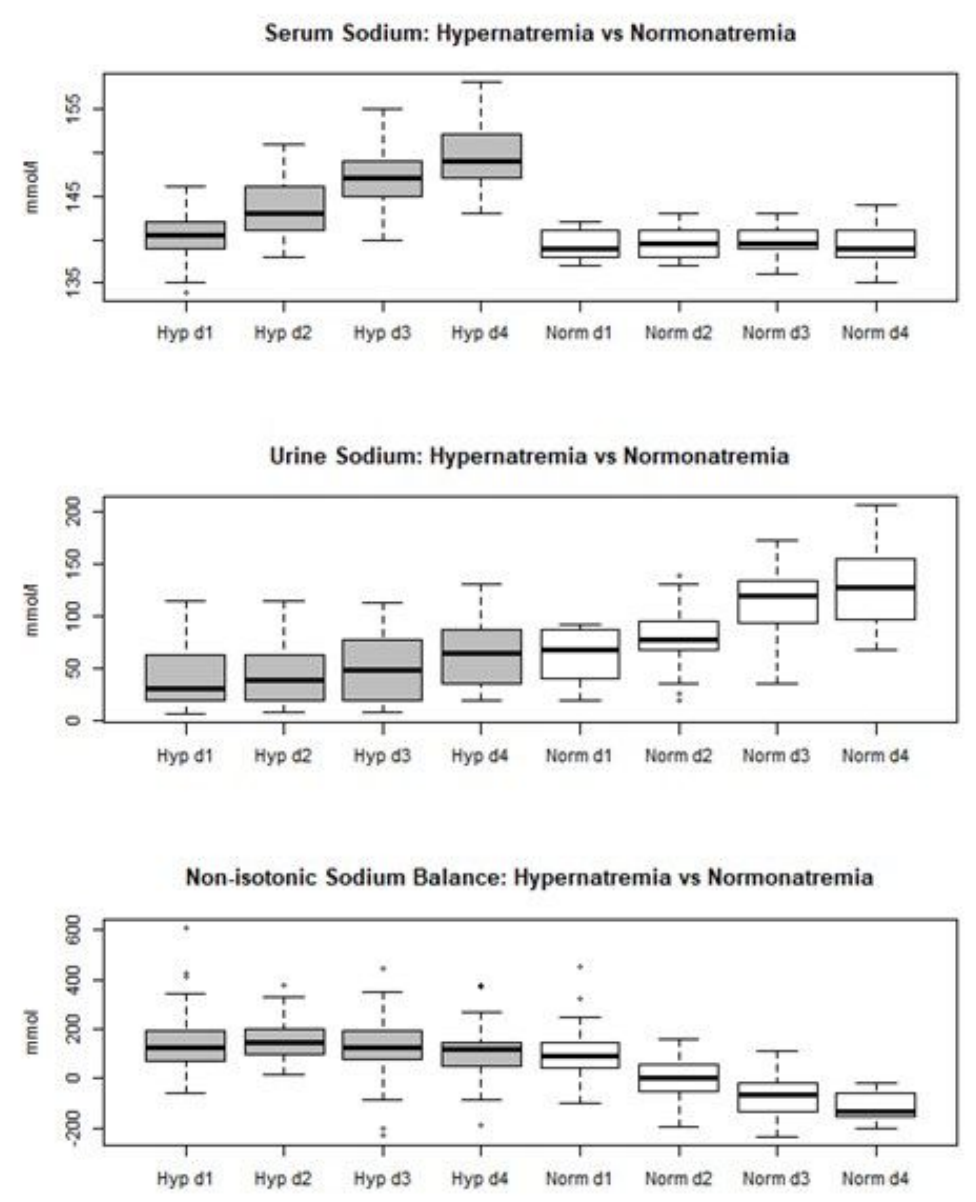

\section{Figure 4}

Selected subgroup of patients ( $n=58$ ) with hypernatremia (grey) four days after major surgery compared to a selected subgroup of patients $(n=27)$ with normonatremia (blue) after major surgery. The development of serum sodium, urine sodium and the balance of non-isotonic sodium are shown. 


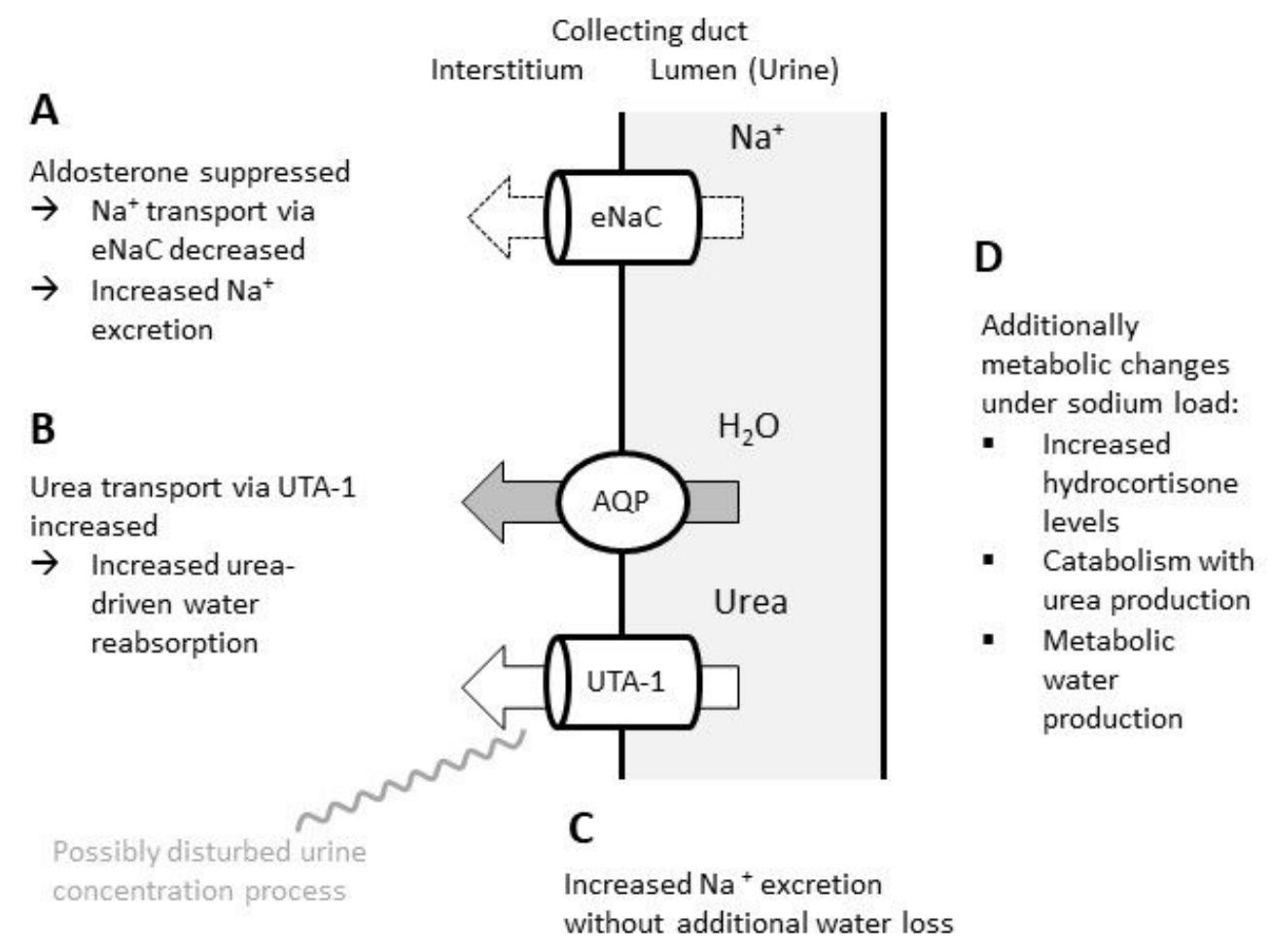

\section{Figure 5}

The concept of natriuretic-ureotelic adaption in response to salt load is supposed to protect against dehydration [7]. (A) Aldosterone must be suppressed to ensure increased salt excretion in the collection tube. (B) In order to prevent salt-induced water excretion, the medullary urea concentration is increased via urea transporter, mainly UTA-1, in the distal collecting tube. (C) The increased medullary urea concentration provides the necessary osmotic driving force to avoid inadequate water loss. (D) Metabolic 
changes with urea production and metabolic water production as further measures to conserve bodywater.

\section{Supplementary Files}

This is a list of supplementary files associated with this preprint. Click to download.

- AdditionalFile.doc 